\title{
SARS-CoV-2 Spike Glycoprotein S1 Induces Neuroinflammation in BV-2 Microglia
}

\author{
Olumayokun A. Olajide ${ }^{1}$ - Victoria U. Iwuanyanwu ${ }^{1}$ - Oyinkansola D. Adegbola ${ }^{1} \cdot$ Alaa A. Al-Hindawi $^{1}$
}

Received: 18 August 2021 / Accepted: 6 October 2021 / Published online: 28 October 2021

(c) The Author(s) 2021

\begin{abstract}
In addition to respiratory complications produced by SARS-CoV-2, accumulating evidence suggests that some neurological symptoms are associated with the disease caused by this coronavirus. In this study, we investigated the effects of the SARS$\mathrm{CoV}-2$ spike protein S1 stimulation on neuroinflammation in BV-2 microglia. Analyses of culture supernatants revealed an increase in the production of TNF- $\alpha$, IL-6, IL-1 $\beta$ and iNOS/NO. S1 also increased protein levels of phospho-p65 and

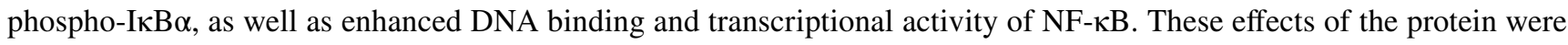
blocked in the presence of BAY11-7082 $(1 \mu \mathrm{M})$. Exposure of S1 to BV-2 microglia also increased the protein levels of NLRP3 inflammasome and enhanced caspase-1 activity. Increased protein levels of p38 MAPK was observed in BV-2 microglia stimulated with the spike protein $\mathrm{S} 1(100 \mathrm{ng} / \mathrm{ml})$, an action that was reduced in the presence of SKF 86,002 $(1 \mu \mathrm{M})$. Results of immunofluorescence microscopy showed an increase in TLR4 protein expression in S1-stimulated BV-2 microglia. Furthermore, pharmacological inhibition with TAK $242(1 \mu \mathrm{M})$ and transfection with TLR4 small interfering RNA resulted in significant reduction in TNF- $\alpha$ and IL-6 production in S1-stimulated BV-2 microglia. These results have provided the first evidence demonstrating S1-induced neuroinflammation in BV-2 microglia. We propose that induction of neuroinflammation by this protein in the microglia is mediated through activation of NF-KB and p38 MAPK, possibly as a result of TLR4 activation. These results contribute to our understanding of some of the mechanisms involved in CNS pathologies of SARS-CoV-2.
\end{abstract}

Keywords SARS-CoV-2 spike protein S1 $\cdot$ Neuroinflammation $\cdot$ Microglia $\cdot$ NF- $\kappa B ~ \cdot T L R 4$

\section{Introduction}

The emergence of the severe acute respiratory syndrome coronavirus-2 (SARS-CoV-2) in 2019 has resulted in a global pandemic affecting most countries and territories. To date, there are 234,809,103 confirmed cases and 4,800,375 deaths [1]. The most common complications of illness due to SARS-CoV-2 infection are mainly related to respiratory symptoms [2-4]. SARS-CoV-2 infection causes significant damage to the alveolus, interstitial and intra-alveolar oedema and infiltration of inflammatory cells (mainly macrophages) [5].

In addition to respiratory complications of SARS-CoV-2 illness, accumulating pieces of evidence suggest that

Olumayokun A. Olajide

o.a.olajide@hud.ac.uk

1 Department of Pharmacy, School of Applied

Sciences, University of Huddersfield, Queensgate,

Huddersfield HD1 3DH, UK neurological symptoms are associated with COVID-19, the disease caused by the novel coronavirus [6]. These symptoms include headaches, loss of smell, confusion and strokes [7]. Furthermore, a retrospective study in China reported neurological symptoms such as cerebrovascular diseases, consciousness impairment and skeletal muscle symptoms [8]. Interestingly, the SARS-CoV-2 sub-unit S1 has been shown in a study to promote loss of barrier integrity and trigger a pro-inflammatory response in a 3D model of the human blood-brain barrier [9], suggesting a possible mechanism for the neurological symptoms induced by the coronavirus. Other studies have proposed mechanisms of SARS-CoV-2-mediated CNS dysfunction [10, 11]. Further understanding of the cellular mechanisms involved in neurological consequences of SARS-CoV-2 infection is critical for identifying pharmacological strategies for prevention and treatment.

Microglia are brain-resident macrophages that regulate brain development, maintenance of neuronal networks and injury repair [12]. In the resting state, microglia survey their 
surrounding microenvironment through the projection and retraction of their highly motile processes [13]. However, in the presence of injury or pathology within the CNS, they become activated [14]. During neuroinflammation, polarised M1 microglia produce pro-inflammatory cytokines and neurotoxic molecules, such as tumour necrosis factor (TNF)- $\alpha$, interleukin (IL)-6, IL-1 $\beta$, nitric oxide (NO) and reactive oxygen species (ROS), which contribute to neuronal dysfunction, while polarised M2 microglia secrete anti-inflammatory mediators such as IL-10 and transforming growth factor (TGF) $-\beta$, which are involved in restoring homeostasis [15-18]. Microglia-mediated neuroinflammation therefore plays significant roles in many neurological [19-23] and neuropsychiatric [24-27] disorders. Based on evidence linking SARS-CoV-2 infection with neurological symptoms, we carried out investigations to determine the effects of a recombinant SARS-CoV-2 spike protein S1 subunit on the release of pro-inflammatory mediators in $\mathrm{BV}-2$ microglia.

\section{Materials and Methods}

\section{Materials}

Recombinant human coronavirus SARS-CoV-2 spike protein S1 (Accession MN908947) was purchased from Abcam. The protein was suspended in sterile water for functional studies. The following drugs were used: BAY11-7082 (Sigma), CRID3 sodium salt (Tocris), SKF 86,002 dihydrochloride (Tocris) and TAK 242 (Tocris).

\section{Cell Culture}

BV-2 mouse microglial cell line (ICLCATL03001) was purchased from Interlab Cell Line Collection (Banca Biologica e Cell Factory, Italy) and cultured in RPMI medium supplemented with $10 \%$ foetal bovine serum.

\section{Determination of Cytokine Production}

Initial pilot experiments were conducted to evaluate effects of $10 \mathrm{ng} / \mathrm{ml}, 50 \mathrm{ng} / \mathrm{ml}, 100 \mathrm{ng} / \mathrm{ml}, 500 \mathrm{ng} / \mathrm{ml}$ and $1000 \mathrm{ng} /$ $\mathrm{ml}$ of $\mathrm{S} 1$ on TNF- $\alpha$ production in BV-2 microglia seeded out in 24-well plates at $5 \times 10^{4}$ cells $/ \mathrm{ml}$. These concentrations of the protein were used to stimulate the cells for $1 \mathrm{~h}, 3 \mathrm{~h}, 6 \mathrm{~h}$, $12 \mathrm{~h}$ and $24 \mathrm{~h}$. Levels of TNF- $\alpha$ in culture supernatants were then determined using mouse instant ELISA ${ }^{\mathrm{TM}}$ kit (Thermo Scientific).

Subsequent experiments employed $10 \mathrm{ng} / \mathrm{ml}, 50 \mathrm{ng} / \mathrm{ml}$ and $100 \mathrm{ng} / \mathrm{ml}$ of $\mathrm{S} 1$ in determining effects on TNF- $\alpha$, IL-6 and IL-1 $\beta$. In this case, cultured BV-2 microglia were seeded out in a 24 -well plate at $5 \times 10^{4}$ cells $/ \mathrm{ml}$ and treated with protein $\mathrm{S} 1(10 \mathrm{ng} / \mathrm{ml}, 50 \mathrm{ng} / \mathrm{ml}$ and $100 \mathrm{ng} / \mathrm{ml})$ for $24 \mathrm{~h}$. Thereafter, medium was collected and centrifuged to obtain culture supernatants. Levels of TNF- $\alpha$ were determined as described above, while levels of IL-6 in supernatants were determined using IL-6 mouse ELISA kit (Thermo Scientific). Similarly, levels of IL- $1 \beta$ were evaluated using IL- $1 \beta$ mouse ELISA kit (Thermo Scientific).

\section{Measurement of NO Production}

The Griess reagent (Promega) was used to determine the levels of NO in supernatants of cultured BV-2 microglia treated with protein $\mathrm{S} 1(10 \mathrm{ng} / \mathrm{ml}, 50 \mathrm{ng} / \mathrm{ml}$ and $100 \mathrm{ng} / \mathrm{ml})$ for $24 \mathrm{~h}$. Following treatment with S1, Griess assay (which measures nitrite, a stable breakdown product of $\mathrm{NO}$ ) was carried out by adding $50 \mu \mathrm{L}$ of sulphanilamide to $50 \mu \mathrm{L}$ of culture supernatants, followed by incubation in the dark at room temperature for $10 \mathrm{~min}$. Thereafter, $50 \mu \mathrm{l}$ of $\mathrm{N}$-(1-naphthyl) ethylenediamine dihydrochloride (NED) was added and the mixture incubated for a further 10-min period. Absorbance was measured at $540 \mathrm{~nm}$ using a Tecan Infinite M microplate reader. Nitrite concentrations were determined from a nitrite standard reference curve.

\section{In-Cell Western/Cytoblot}

The In-Cell Western assay is a proven method for the rapid quantification of proteins in cells [28, 29]. BV-2 microglia were seeded into a 96 -well plate at $5 \times 10^{4}$ cells $/ \mathrm{ml}$, and cells treated at $70 \%$ confluence. At the end of each experiment, cells were fixed with $8 \%$ formaldehyde solution $(100 \mu \mathrm{L})$ for 15 min, followed by washing with PBS. The cells were then incubated with primary antibodies overnight at $4{ }^{\circ} \mathrm{C}$. The following antibodies were used: rabbit anti-iNOS (Abcam), rabbit anti-phospho-p65 (Cell Signalling Technology), rabbit anti-phospho-IкB $\alpha$ (Santa Cruz Biotechnology), rabbit anti-NLRP3 (Abcam) and rabbit anti-phospho-p38 (Cell Signalling Technology) antibodies. Thereafter, cells were washed with PBS and incubated with anti-rabbit HRP secondary antibody for $2 \mathrm{~h}$ at room temperature. Then, $100 \mu \mathrm{l}$ of HRP substrate was added to each well and absorbance measured at $450 \mathrm{~nm}$ with a Tecan Infinite M microplate reader. Readings were normalised with Janus Green normalisation stain (Abcam).

\section{NF-KB Luciferase Reporter Gene Assay}

BV-2 cells were seeded in a 24-well plate at a density of $4 \times 10^{4}$ cells $/ \mathrm{ml}$. At $60 \%$ confluence, RPMI medium was replaced with Opti-MEM, with a further incubation period of $2 \mathrm{~h}$ at $37^{\circ} \mathrm{C}$. Transfection of BV-2 cells was performed by preparing a Glial-Mag transfection reagent (OZ Biosciences) and Cignal NF- $\mathrm{KB}$ luciferase reporter (Qiagen) complex at 
a ratio of 3:1 in $50 \mu \mathrm{L}$ Opti-MEM. The complex was added to $\mathrm{BV}-2$ cells, and the plate placed on a magnetic plate $(\mathrm{OZ}$ Biosciences) and incubated at $37{ }^{\circ} \mathrm{C}$ for $30 \mathrm{~min}$, followed by a further magnetic plate-free incubation period of $2 \mathrm{~h}$.

Thereafter, the medium was changed to serum-free RPMI and cells were treated with spike $\mathrm{S} 1(10 \mathrm{ng} / \mathrm{ml}, 50 \mathrm{ng} / \mathrm{ml}$ and $100 \mathrm{ng} / \mathrm{ml}$ ) for $6 \mathrm{~h}$. This was followed by a Dual-Glo® reporter assay (Promega). Firefly and Renilla luminescence were measured using a FLUOstar OPTIMA microplate reader (BMG Labtech).

\section{NF-kB Transcription Factor Binding Assay}

The NF- $\kappa B$ p 65 transcription factor assay is a non-radioactive ELISA-based assay for evaluating DNA binding activity of NF- $\kappa B$ in nuclear extracts. BV-2 microglia were seeded in a 6-well plate at a density of $4 \times 10^{4}$ cells $/ \mathrm{ml}$. The cells were then incubated with $10 \mathrm{ng} / \mathrm{ml}, 50 \mathrm{ng} / \mathrm{ml}$ and $100 \mathrm{ng} / \mathrm{ml}$ of $\mathrm{S} 1 \mathrm{for} 60 \mathrm{~min}$. At the end of the incubation, nuclear extracts were prepared from the cells and subjected to NF- $\mathrm{\kappa B}$ transcription factor binding assay according to the instructions of the manufacturer (Abcam).

\section{Caspase-Glo ${ }^{\circledR} 1$ Inflammasome Assay}

The Caspase-Glo® 1 Inflammasome Assay (Promega) was used to measure the activity of caspase- 1 directly in live cells or culture supernatants [30]. BV-2 microglia were seeded out in a 24-well plate at a density of $4 \times 10^{4}$ cells $/ \mathrm{ml}$ and stimulated with $\mathrm{S} 1(10 \mathrm{ng} / \mathrm{ml}, 50 \mathrm{ng} / \mathrm{ml}$ and $10 \mathrm{ng} / \mathrm{ml})$ for $24 \mathrm{~h}$. After incubation, cell culture supernatants were collected and mixed with an equal volume of Caspase-Glo ${ }^{\circledR}$ 1 reagent or Caspase-Glo ${ }^{\circledR} 1$ reagent + YVAD-CHO $(1 \mu \mathrm{M})$ in a 96-well plate. The contents of the wells were mixed using a plate shaker at $400 \mathrm{rpm}$ for $30 \mathrm{~s}$. The plate was then incubated at room temperature for $60 \mathrm{~min}$, followed by luminescent measurement of caspase-1 activity with a FLUOstar OPTIMA reader (BMG Labtech).

\section{Effects of BAY11-7082, CRID3 and SKF 86002 on S1-Induced Neuroinflammation}

BAY11-7082 is an anti-inflammatory small molecule inhibitor of NF- $\mathrm{KB}$, which has also been proposed as a potential disease-modifying strategy to combat the severity of COVID-19 [31]. CRID3 is an NLRP3 inflammasome inhibitor, which has been shown to reduce IL- $1 \beta$ production in vivo and attenuate the severity of experimental autoimmune encephalomyelitis [32]. SKF 86,002 is a bicyclic pyridinylimidazole which has been widely reported to inhibit cytokine production by targeting p38 MAPK [33].

Consequently, the effects of these inhibitors on the release of TNF- $\alpha$, IL- 6 and IL- $1 \beta$ were investigated by pre-treating
BV-2 microglia with BAY11-7082 (1 $\mu \mathrm{M})$, CRID3 (1 $\mu \mathrm{M})$ and SKF 86,002 $(1 \mu \mathrm{M}) 60 \mathrm{~min}$ prior to stimulation with S1 $(100 \mathrm{ng} / \mathrm{ml})$ for a further $24-\mathrm{h}$ period. Culture supernatants were collected and analysed for levels of TNF- $\alpha$, IL- 6 and IL-1 $\beta$ using mouse ELISA kits (Thermo Scientific).

\section{Immunofluorescence Microscopy}

Immunofluorescence microscopy was carried out by seeding out BV-2 microglia in a 24-well cell imaging plate (Eppendorf) at a density of $5 \times 10^{4}$ cells $/ \mathrm{ml}$. Thereafter, cells were stimulated with S1 $(100 \mathrm{ng} / \mathrm{ml})$ for $24 \mathrm{~h}$. After stimulation, cells were washed with PBS and fixed with $500 \mu \mathrm{l}$ formaldehyde (4\%) for $15 \mathrm{~min}$ at room temperature. This was followed by PBS washing and blocking with $500 \mu \mathrm{l}$ of $5 \%$ bovine serum albumin for $60 \mathrm{~min}$ at room temperature. Cells were then incubated overnight at $4{ }^{\circ} \mathrm{C}$ with either Iba- 1 Alexa Fluor ${ }^{\circledR} 488$ antibody (Santa Cruz Biotechnology; 1:500) or Toll-like receptor 4 (TLR4) antibody (Santa Cruz Biotechnology; 1:500). In experiments employing unconjugated primary antibody, cells were washed with PBS and further incubated in the dark for $2 \mathrm{~h}$ with Alexa Fluor ${ }^{\circledR}$ 488-conjugated donkey anti-rabbit IgG secondary antibody (Thermo Scientific; 1:500). Then, cells were stained with $50 \mathrm{nM}$ of 4',6-diamidino-2-phenylindole dihydrochloride (DAPI; Invitrogen) for 3 min and washed. Images were captured using EVOS FLoid $®$ cell imaging station (Invitrogen).

\section{Effects of TAK 242 on Spike Protein S1-Induced Increased Production of Pro-inflammatory Mediators}

TAK 242 is a small molecule inhibitor of inflammation which has been reported to reduce nitric oxide and cytokine production in LPS-stimulated mouse macrophages and in a mouse model [34]. The anti-inflammatory activity of TAK 242 has been confirmed to be mediated through inhibition of TLR4 signalling [35]. The effects of TAK 242 were therefore investigated on $\mathrm{S} 1$-induced increased production of TNF- $\alpha$, IL- 6 and IL-1 $\beta$. BV- 2 microglia were pre-treated with TAK $242(1 \mu \mathrm{M})$. After $60 \mathrm{~min}$, cells were stimulated with S1 $(100 \mathrm{ng} / \mathrm{ml})$ for a further $24-\mathrm{h}$ period. Levels of TNF- $\alpha$ and IL-6 in culture supernatants were measured using mouse ELISA kits (Thermo Scientific).

\section{Small Interfering RNA-Mediated Knockdown of TLR4}

In order to further confirm the possible roles of TLR4 in S1-induced increased production of pro-inflammatory mediators, experiments were carried out to knockdown TLR4 in BV-2 microglia. BV-2 cells were seeded out into 6-well plates at a concentration of $4 \times 10^{4}$ cells $/ \mathrm{ml}$ and cultured 
until $60 \%$ confluence was achieved. Thereafter, the culture medium in each well was changed to Opti-MEM (1000 $\mu \mathrm{l})$ followed by incubation for $2 \mathrm{~h}$ at $37^{\circ} \mathrm{C}$. Complexes containing $1.8 \mu \mathrm{l}$ of the Glial-Mag transfection reagent (OZ Biosciences) and $2 \mu$ of TLR4 or control small interfering RNA (siRNA) (Santa Cruz Biotechnology) were then added to the cells. The culture plate was placed on a magnetic plate $(\mathrm{OZ}$ Biosciences) for $30 \mathrm{~min}$, followed by incubation at $37^{\circ} \mathrm{C}$ for a further 24-h period. Following successful transfection, the effects of loss of function of TLR4 were evaluated by stimulating the cells with SARS-CoV-2 spike protein S1 (100 ng/ $\mathrm{ml})$ for $24 \mathrm{~h}$. Culture supernatants were collected and analysed for levels of TNF- $\alpha$ and IL- 6 using mouse ELISA kits.

\section{Statistical Analyses}

Data are expressed as mean \pm SEM for at least three independent experiments $(n=3)$ and analysed using one-way analysis of variance (ANOVA) with post hoc Tukey's test (for multiple comparisons). Statistical analysis was conducted using GraphPad Prism software (version 9).

\section{Results}

\section{Effects of S1 on Pro-inflammatory Cytokine Release in BV-2 Microglia}

Results of pilot experiments to determine effects of stimulation with $10 \mathrm{ng} / \mathrm{ml}, 50 \mathrm{ng} / \mathrm{ml}, 100 \mathrm{ng} / \mathrm{ml}, 500 \mathrm{ng} / \mathrm{ml}$ and $1000 \mathrm{ng} / \mathrm{ml}$ of $\mathrm{S} 1$ on the production of TNF- $\alpha$ in BV-2 microglia at $1 \mathrm{~h}, 3 \mathrm{~h}, 6 \mathrm{~h}, 12 \mathrm{~h}$ and $24 \mathrm{~h}$ are shown in the Supplementary Data. Stimulation with all concentrations of the spike protein resulted in a steady increase in the production of TNF- $\alpha$ from $1 \mathrm{~h}$ post-stimulation, with the maximum release observed $24 \mathrm{~h}$ post-stimulation.

Furthermore, there was a concentration-dependent increase in $\mathrm{S} 1$-induced increase in $\mathrm{TNF}-\alpha$ production, which reached a maximum at $100 \mathrm{ng} / \mathrm{ml}$ at $3 \mathrm{~h}, 6 \mathrm{~h}, 12 \mathrm{~h}$ and $24 \mathrm{~h}$ post-stimulation. When compared with effects of $100 \mathrm{ng} / \mathrm{ml}$ of $\mathrm{S} 1$, there were no further significant increases in TNF- $\alpha$ production when the concentration of S1 was increased to $500 \mathrm{ng} / \mathrm{ml}$ and $1000 \mathrm{ng} / \mathrm{ml}$.

Consequently, in subsequent confirmatory experiments, $10 \mathrm{ng} / \mathrm{ml}, 50 \mathrm{ng} / \mathrm{ml}$ and $100 \mathrm{ng} / \mathrm{ml}$ of S1 were then incubated with BV-2 cells for $24 \mathrm{~h}$. Results show that with $10 \mathrm{ng} / \mathrm{ml}$ of $\mathrm{S} 1$, there was an insignificant $(p<0.05)$ elevation in the secretion of TNF- $\alpha$. However, on increasing the concentration to $50 \mathrm{ng} / \mathrm{ml}$, a significant $(p<0.05)$ increase in the production of TNF- $\alpha$ was observed (Fig. 1A). On increasing the concentration of the protein to $100 \mathrm{ng} / \mathrm{ml}$, there was $\mathrm{a} \sim 15$-fold increase in the levels of TNF- $\alpha$ in culture supernatants (Fig. 1A).

\section{S1 Induced an Increase in IL-6 and IL-1 $\beta$ Production}

Results in Fig. 1B show that the release of IL-6 was not significantly elevated in BV-2 microglia treated with $10 \mathrm{ng} / \mathrm{ml}$ and $50 \mathrm{ng} / \mathrm{ml}$ of $\mathrm{S} 1$, in comparison with untreated (control) cells. However, incubation of the cells with $100 \mathrm{ng} / \mathrm{ml}$ of S1 resulted in a $\sim 10.2$-fold and significant $(p<0.001)$ increase in the secretion of IL-6 into culture medium. Similar observations were made in experiments to determine the effects of S1 sub-unit on IL-1 $\beta$ production; at $10 \mathrm{ng} / \mathrm{ml}$ and $50 \mathrm{ng} /$ $\mathrm{ml}$ of $\mathrm{S} 1$, there was no significant effect on the release of IL-1 $\beta$. A 5.5-fold elevation of IL- $1 \beta$ levels was, however, observed with $100 \mathrm{ng} / \mathrm{ml}$ of S1 (Fig. 1C).

\section{S1 Induced an Increase in NO Production and iNOS Protein Expression in BV-2 Microglia}

Analyses of culture supernatants obtained from BV-2 microglia incubated with $\mathrm{S} 1(10 \mathrm{ng} / \mathrm{ml})$ showed an insignificant $(p<0.05)$ increase in the levels of NO, when compared with untreated (control) cells. We further showed that incubation with $50 \mathrm{ng} / \mathrm{ml}$ and $100 \mathrm{ng} / \mathrm{ml}$ of $\mathrm{S} 1$ caused a $\sim 5.1$ and 8.7 increase in NO production, respectively $(p<0.01)$ (Fig. 2A).

We also used In-Cell Western analyses to further demonstrate that incubation with $\mathrm{S} 1(50 \mathrm{ng} / \mathrm{ml}$ and $100 \mathrm{ng} / \mathrm{ml})$ resulted in a significant $(p<0.05)$ increase in protein levels of iNOS, in comparison with unstimulated cells (Fig. 2B).

\section{S1 Increased Iba-1 Expression in BV-2 Microglia}

Immunofluorescence microscopy revealed that unstimulated BV-2 microglia express low levels of Iba-1 protein. However, on activation with $\mathrm{S} 1(10-100 \mathrm{ng} / \mathrm{ml})$, there were marked increases in the expression of Iba-1 (Fig. 3).

\section{Spike Protein S1 Activated NF-KB in BV-2 Microglia}

Following our observation that S1 induced a significant increase in the production of pro-inflammatory mediators at $100 \mathrm{ng} / \mathrm{ml}$, we were next interested in evaluating the role of NF- $\mathrm{kB}$ in its activity at this concentration. Firstly, we used In-Cell Western assays to investigate effects of the protein on the cytoplasmic activation of $\mathrm{p} 65$ and I $\mathrm{I} B \alpha$. Results show that $\mathrm{S} 1(100 \mathrm{ng} / \mathrm{ml})$ significantly $(p<0.01)$ increased protein levels of both phospho-p65 and phospho-IкB $\alpha$ following incubation with BV-2 microglia for 15 min (Fig. 4A, B). These results also show that protein levels of phosphop65 and phospho-I $\mathrm{B} \alpha$ were reduced in the presence of the NF- $\kappa B$ inhibitor BAY11-7082 (1 $\mu \mathrm{M})$. 
A

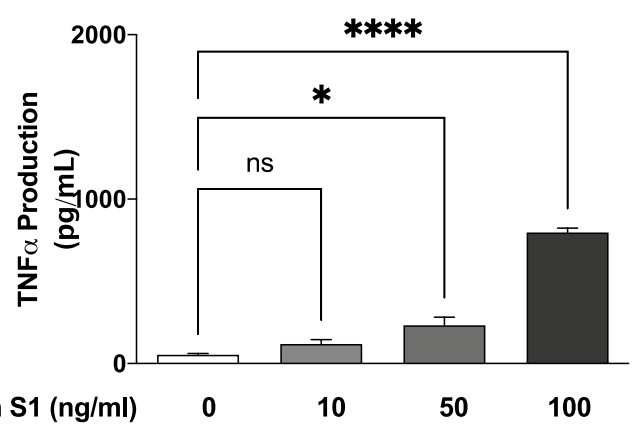

B

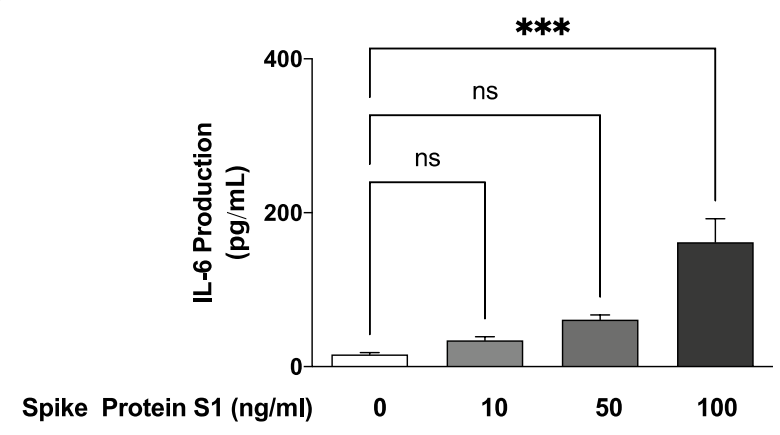

C

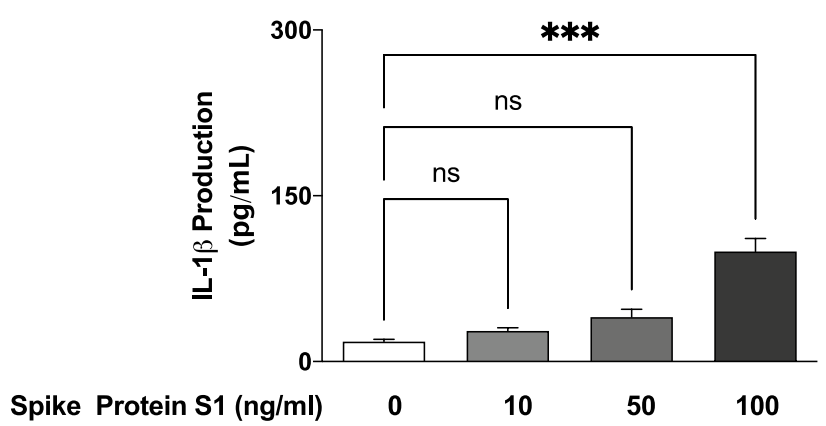

Fig. 1 S1 increased levels of TNF- $\alpha(\mathbf{A})$, IL-6 (B) and IL-1 $\beta$ (C) in BV-2 microglia after a 24-h incubation. All values are expressed as mean \pm SEM for three independent experiments. Data were analysed

using one-way ANOVA followed by a post hoc Tukey's multiple comparison test. ${ }^{*} p<0.05, * * * p<0.001$, $* * * * p<0.0001$, ns (not significant at $p<0.05)$, compared with untreated control

Results of an NF- $\kappa \mathrm{B}$ p65 transcription factor assay revealed that following the treatment of $\mathrm{BV}-2$ microglia with $\mathrm{S} 1(100 \mathrm{ng} / \mathrm{ml})$ for $60 \mathrm{~min}$, there was a significant $(p<0.001)$ increase in the binding of NF- $\mathrm{KB}$ in nuclear extracts to consensus binding sites in the DNA. Interestingly, pre-treatment of BV-2 cells with BAY11-7082 $(1 \mu \mathrm{M})$ prior to stimulation with $\mathrm{S} 1$ produced an inhibition in binding to a doublestranded DNA sequence containing the NF- $\mathrm{KB}$ response

A

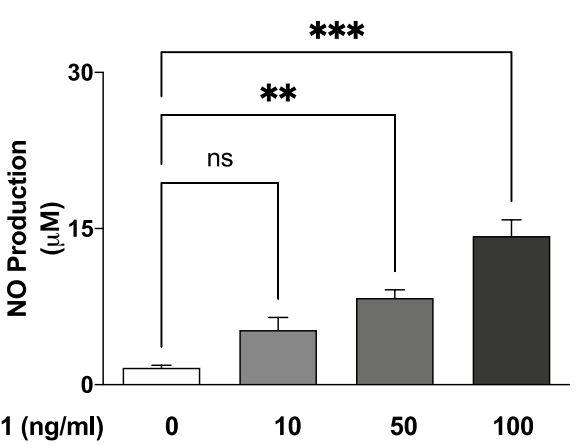

Fig. 2 S1 increased levels of NO (A) and iNOS protein (B) in BV-2 microglia after a 24-h incubation. NO levels in culture supernatants were measured using the Griess assay, while In-Cell Western (cytoblot) assay was used to detect iNOS protein expression. All values are element (Fig. 4C). Luciferase reporter gene assays to evaluate the effects of $\mathrm{S} 1$ on transcriptional activity showed that $\mathrm{S} 1$ stimulation of BV-2 microglia that were transfected with NF-KB plasmid vector resulted in a significant $(p<0.01)$ increase in luciferase activity, in comparison with untreated transfected cells. We further showed that on pre-treating the cells with BAY11-7082 $(1 \mu \mathrm{M})$, an S1-induced increase in NF-KB luciferase activity was markedly reduced (Fig. 4D).

B

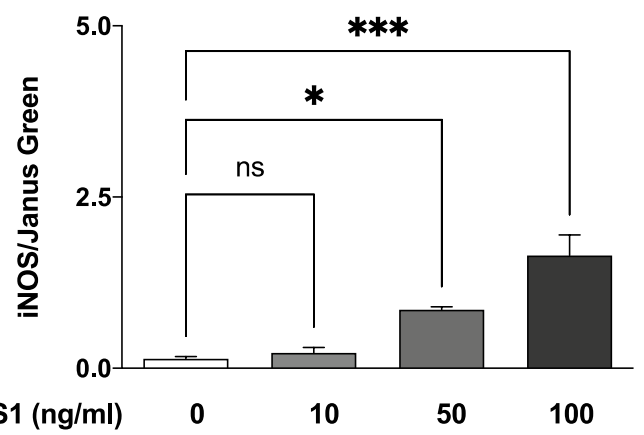

expressed as mean \pm SEM for three independent experiments. Data were analysed using one-way ANOVA followed by a post hoc Tukey's multiple comparison test. $* p<0.05, * * p<0.01$, $* * * p<0.001$, ns (not significant at $p<0.05$ ), compared with untreated control 


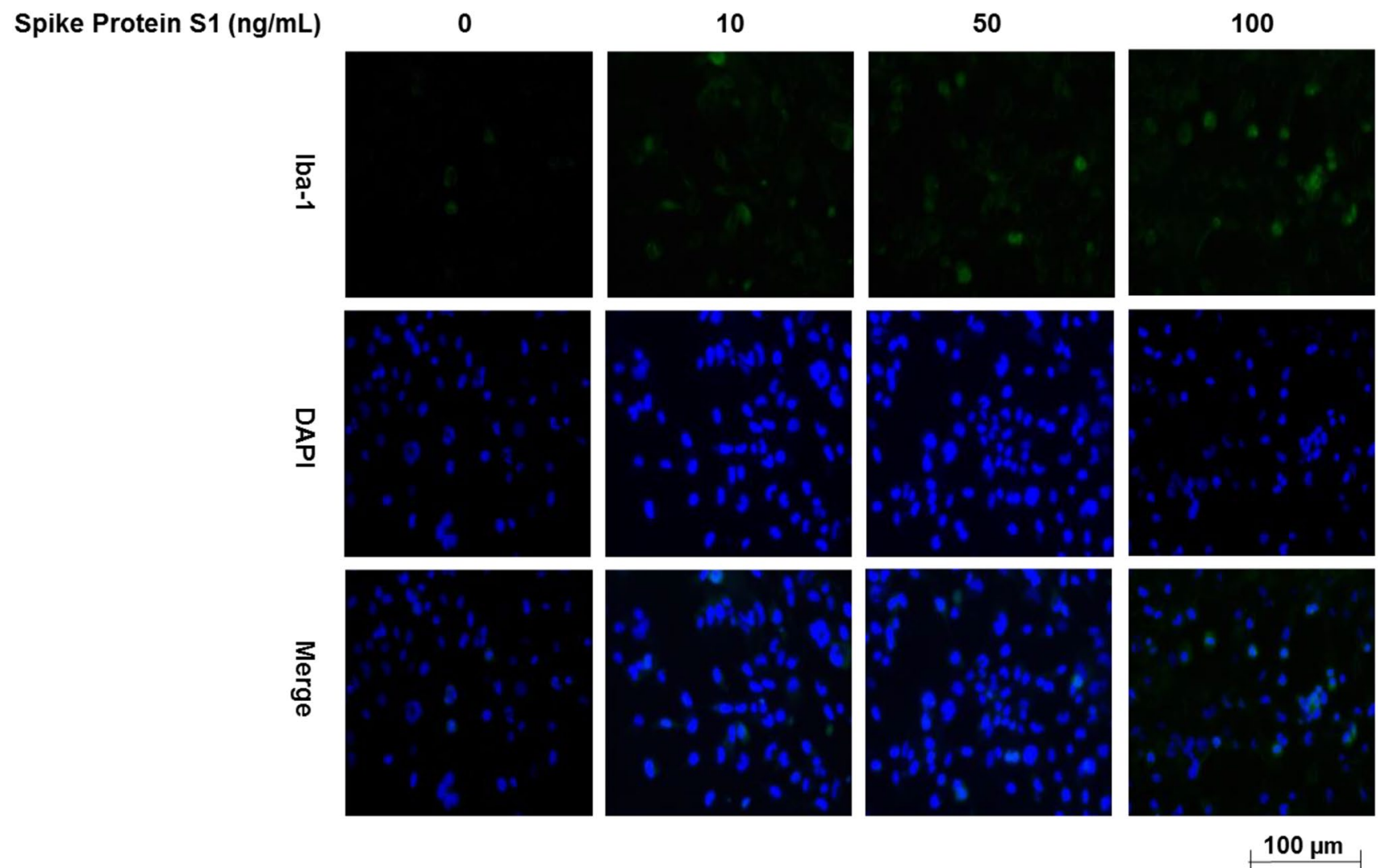

Fig. 3 Immunofluorescence microscopy showing an increase in Iba-1 protein expression in BV-2 microglia incubated with $10 \mathrm{ng} / \mathrm{ml}, 50 \mathrm{ng} / \mathrm{ml}$ and $100 \mathrm{ng} / \mathrm{ml}$ of $\mathrm{S} 1$

\section{Pre-treatment with BAY11-7082 Reduced S1-Induced Production of Pro-inflammatory Mediators}

In order to further confirm the roles of NF- $\mathrm{kB}$ in S1-induced neuroinflammation, BV-2 microglia were pre-treated with BAY11-7082 prior to stimulation with the protein for $24 \mathrm{~h}$, followed by measurements of the release of pro-inflammatory cytokines (TNF- $\alpha$, IL- 6 and IL-1 $\beta$ ) in culture supernatants. In the presence of BAY11-7082 $(1 \mu \mathrm{M})$, S1-induced increases in TNF- $\alpha$, IL- 6 and IL- $1 \beta$ production in BV-2 microglia were reduced by $\sim 59.6 \%, \sim 40.6 \%$ and $\sim 32.8 \%$, respectively (Fig. 5A-C).

Results in Fig. 5D and E also show that an S1-induced increase in NO production and iNOS protein expression was significantly $(p<0.01)$ reduced when the cells were treated with BAY11-7082 $(1 \mu \mathrm{M})$ prior to $\mathrm{S} 1$ stimulation.

\section{S1 Triggers Activation of NLRP3 Inflammasome/ Caspase-1 in BV-2 Microglia}

The NLRP3 inflammasome is known to contribute to the secretion of IL-1 $\beta$ during inflammation. Encouraged by results of experiments showing an increase in the production of this cytokine following BV-2 stimulation with S1, we next investigated its effect on protein levels of NLRP3 in the presence and absence of known NLRP3 inhibitors, CRID3 and BAY11-7082. Cytoblot analyses revealed that stimulation of BV-2 microglia with $\mathrm{S} 1(100 \mathrm{ng} / \mathrm{ml})$ for $6 \mathrm{~h}$ resulted in an $\sim 11$-fold increase in levels of NLRP3 protein. We also observed that an S1-induced increase in NLRP3 protein levels was significantly reduced $(p<0.05)$ in the presence of CRID3 $(1 \mu \mathrm{M})$ and BAY11-7082 $(1 \mu \mathrm{M})$ (Fig. 6A).

We next determined measured caspase-1 activity in culture media of BV-2 cells that were stimulated with $\mathrm{S} 1$ for 6 h. Results in Fig. 6B show a $\sim 4$.4-fold increase in caspase-1 activity as a result of $\mathrm{S} 1$ stimulation. Furthermore, both CRID3 $(1 \mu \mathrm{M})$ and BAY11-7082 $(1 \mu \mathrm{M})$ produced significant $(p<0.001)$ inhibition in S1-induced increased caspase-1 activity.

\section{CRID3 Prevented S1-Induced Increase in IL-1 $\beta$ Production}

Experiments to evaluate the effects of CRID3 on S1-induced increased secretion of TNF- $\alpha$, IL- 6 and IL- $1 \beta$ in BV- 2 microglia revealed that pre-treatment with CRID3 $(1 \mu \mathrm{M})$ was ineffective in reducing TNF- $\alpha$ (Fig. 7A) and IL-6 (Fig. 7B) 


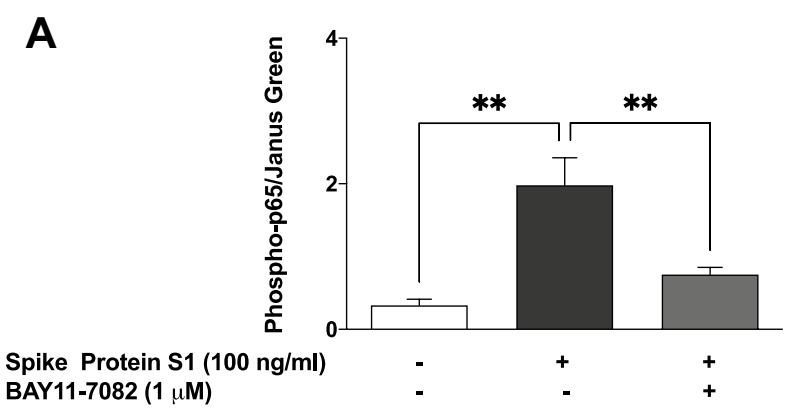

C

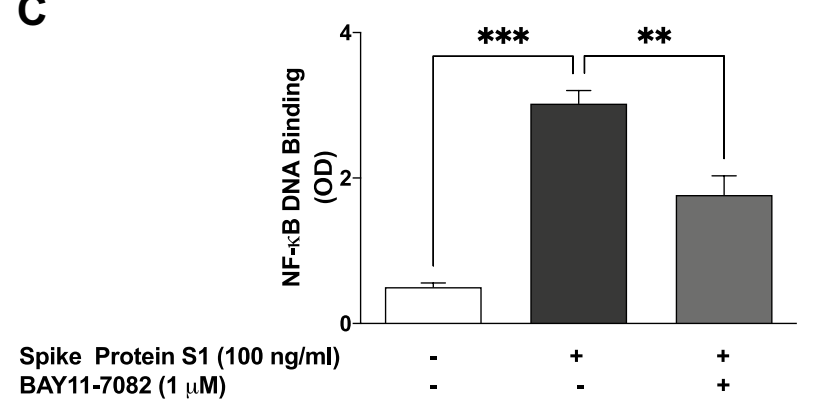

Fig. $4 \mathrm{~S} 1$ activated NF- $\mathrm{KB}$ signalling in BV-2 microglia. Nuclear extracts were collected from cells stimulated with $\mathrm{S} 1(100 \mathrm{ng} / \mathrm{ml})$ in the absence or presence of BAY11-7082 $(1 \mu \mathrm{M})$ for $60 \mathrm{~min}$ and subjected to DNA binding assays (A). Results of luciferase reporter gene assay showing increased NF- $\mathrm{KB}$ transcriptional activity by $\mathrm{S} 1$ and its inhibition by BAY11-7082 $(1 \mu \mathrm{M})(\mathbf{B})$. In-Cell Western (cytoblot) analyses showing increased protein expressions of phospho-p65

production. However, pre-treatment of S1-stimulated BV-2 cells with CRID3 significantly $(p<0.001)$ reduced IL- $1 \beta$ production (Fig. 7C). We also observed that S1-induced NO production was not reduced by pre-treatment with CRID3 (Fig. 7D).

\section{S1 Activated p38 MAP Kinase in BV-2 Microglia}

Incubation of spike protein S1 (100 ng/ml) with BV-2 microglia for 60 min resulted in a significant $(p<0.01)$ and $\sim 11.3-$ fold increase in protein levels of phospho-p38, an outcome that was prevented by pre-treating the cells with SKF $86002(1 \mu \mathrm{M})$ for $60 \mathrm{~min}$ prior to $\mathrm{S} 1$ stimulation (Fig. 8A).

Based on the results showing that $\mathrm{S} 1$ caused an increase in protein levels of phospho-p38 and its inhibition by SKF 86,002 , we were next interested to determine the effects of this inhibitor on cytokine production in S1-stimulated BV-2 microglia. In the presence of SKF $86002(1 \mu \mathrm{M})$, TNF- $\alpha$ production was reduced by $\sim 47.9 \%$ compared with $\mathrm{S} 1$ alone (Fig. 8B). Similarly, S1-induced increased production of IL-6 was significantly $(p<0.05)$ reduced in the presence of SKF $86002(1 \mu \mathrm{M})$ (Fig. 8C). However, there was an insignificant reduction in the production of IL-1 $\beta$ by SKF 86002 (Fig. 8D).
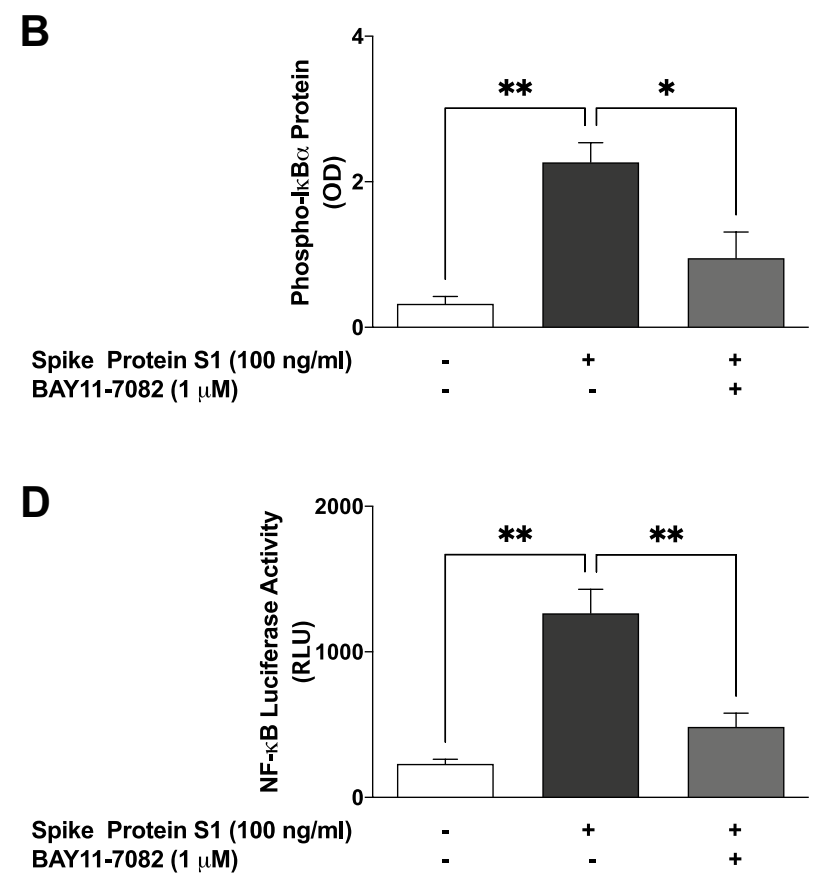

sub-unit (C) and phospho-IкB $\alpha(\mathbf{D})$ following stimulation with $\mathrm{S} 1$ $(100 \mathrm{ng} / \mathrm{ml})$ for $15 \mathrm{~min}$ and inhibition by BAY11-7082 $(1 \mu \mathrm{M})$. Data were analysed using one-way ANOVA followed by a post hoc Tukey's multiple comparison test. $* p<0.05, * * p<0.01, * * * p<0.001$, ns (not significant at $p<0.05$ ), compared with untreated control or S1 stimulation alone

\section{S1-Induced Increased Production of TNF- $\alpha$ and IL- 6 Was Reduced by TAK 242 and TLR4 siRNA}

Immunofluorescence microscopy revealed that stimulation of BV-2 microglia with $100 \mathrm{ng} / \mathrm{ml} \mathrm{S1}$ resulted in a marked increase in TLR4 expression (Fig. 9A). Further experiments showed that pre-treatment with the TLR4 signalling inhibitor TAK $242(1 \mu \mathrm{M})$ resulted in a significant $(p<0.05)$ reduction in the production of TNF- $\alpha$ and IL-6 (Fig. 9B, C).

Furthermore, TLR4 knockdown experiments revealed that TNF- $\alpha$ production was significantly $(p<0.01)$ reduced in S1-stimulated BV-2 microglia transfected with TLR4 siRNA, in comparison with cells transfected with control siRNA (Fig. 9D). Similarly, TLR4 knockdown resulted in reduced IL-6 production, when compared with control (Fig. 9E).

\section{Discussion}

During SARS-CoV-2 infection, viral attachment, fusion and entry into the host's cells are facilitated by the spike proteins which protrude from the surface of mature virions, by binding to the host ACE2 protein $[36,37]$. 
A

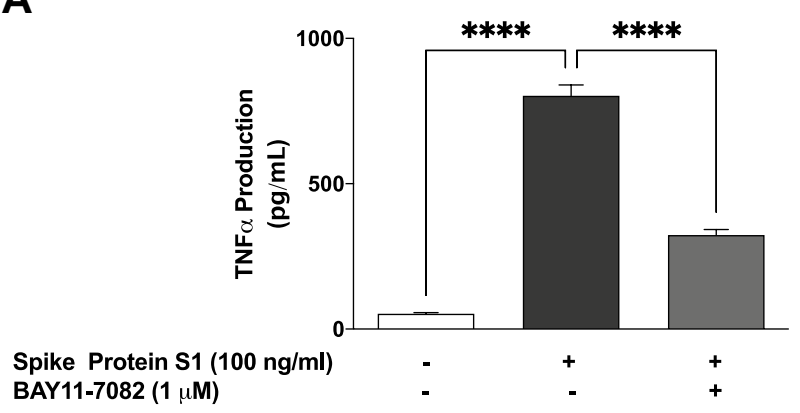

C

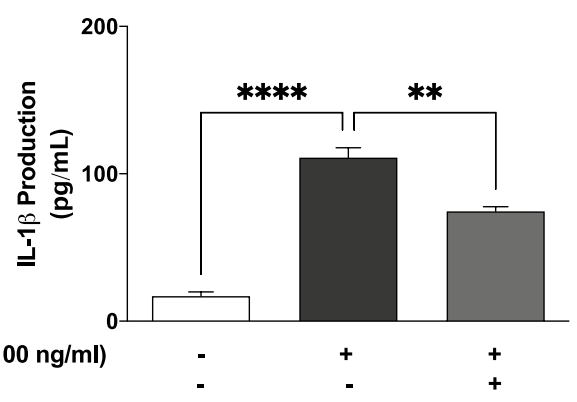

B

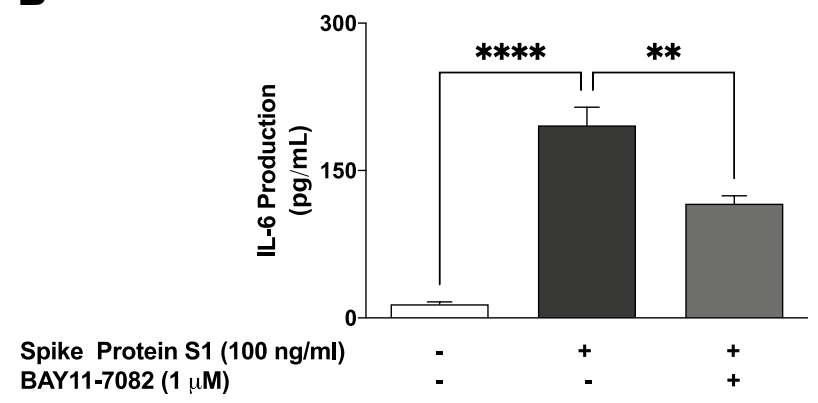

D

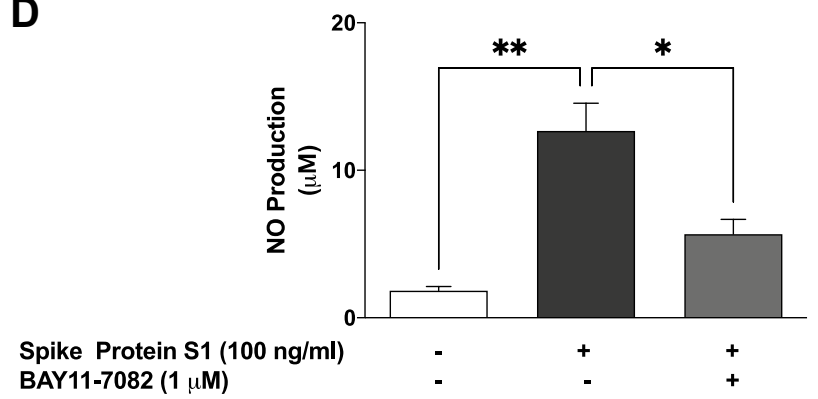

E

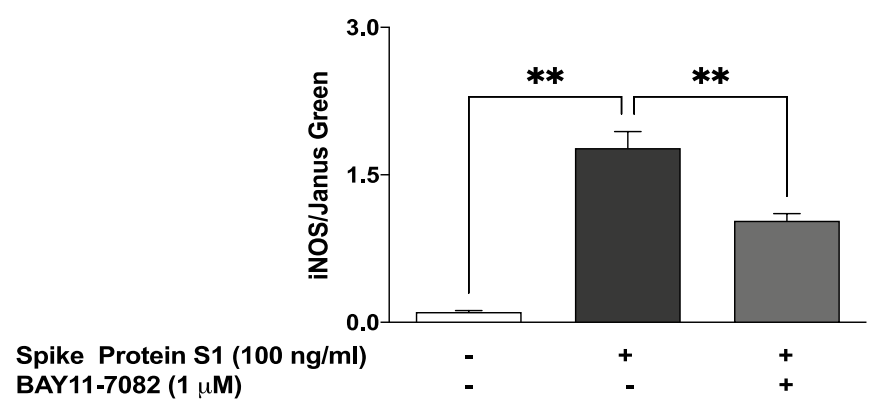

Fig. 5 Pre-treatment with BAY11-7082 $(1 \mu \mathrm{M})$ resulted in inhibition of S1-induced increased production of TNF- $\alpha$ (A), IL-6 (B) and IL-1 $\beta(\mathbf{C})$ in BV-2 microglia. Culture supernatants were analysed using ELISA following stimulation for $24 \mathrm{~h}$. Data were analysed using one-way ANOVA followed by a post hoc Tukey's multiple comparison test. $* * p<0.01$, $* * * p<0.0001$, compared with untreated control or S1 stimulation alone. Pre-treatment with BAY11-
$7082(1 \mu \mathrm{M})$ resulted in inhibition of S1-induced increased production of NO (D) and iNOS protein (E) in BV-2 microglia, following stimulation for $24 \mathrm{~h}$. Culture supernatants were analysed using Griess assay, and In-Cell Western (cytoblot) was used for iNOS detection. Data were analysed using one-way ANOVA followed by a post hoc Tukey's multiple comparison test. $* p<0.05$, ** $p<0.01$, compared with untreated control or S1 stimulation alone
However, accumulating pieces of evidence show that in addition to facilitating its fusion to the cell membrane, the location of the spike protein on SARS-CoV-2 also makes it a direct target for host immune responses [36]. With respect to immune responses induced by SARS-CoV-2 infection, it is now established that this may involve an exaggerated inflammation, also known as cytokine storm [38-40]. Recently, we reported induction of increased release of pro-inflammatory cytokines in human peripheral blood mononuclear cells stimulated with the recombinant SARS-CoV-2 spike protein sub-unit S1, further confirming the role of the spike protein in COVID-19 cytokine storm [41].

In this study, we showed for the first time that the recombinant SARS-CoV-2 spike protein sub-unit S1 activated BV-2 microglia as demonstrated by an increase in the protein expression of Iba-1, which is mainly expressed by the microglia and increased by the activation of these cells [42, 43]. We further demonstrated that activation of $\mathrm{BV}-2$ microglia by $\mathrm{S} 1$ resulted in the increased release of TNF- $\alpha$, IL- 6 and IL-1 $\beta$, which are hallmarks of neuroinflammation. Activation of neuroinflammatory processes 
A

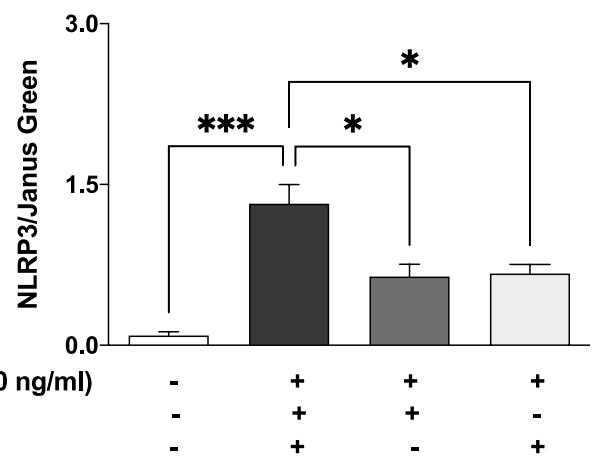

Fig. 6 A Stimulation of BV-2 microglia with S1 (100 ng/ml) increased the protein expression of NLRP3 inflammasome and was inhibited in the presence of CRID3 $(1 \mu \mathrm{M})$ and BAY11-7082 $(1 \mu \mathrm{M})$. B Increased caspase-1 activity by $\mathrm{S} 1(100 \mathrm{ng} / \mathrm{ml}) \mathrm{BV}-2$ microglia was reduced in the presence of CRID3 $(1 \mu \mathrm{M})$ and BAY11-7082

A

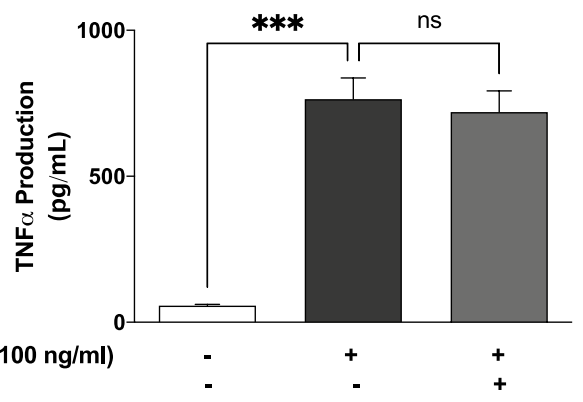

C

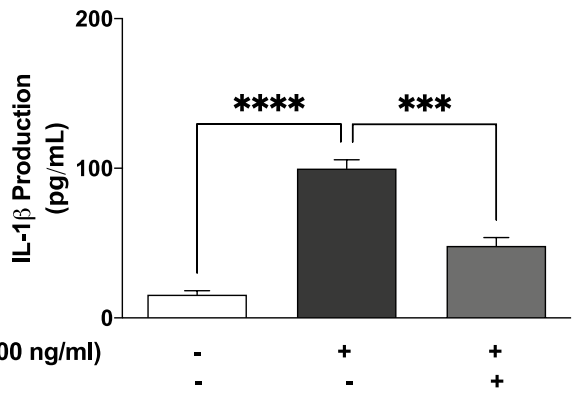

Fig. 7 Pre-treatment with CRID3 $(1 \mu \mathrm{M})$ did not prevent the S1-induced increased production of TNF- $\alpha(\mathbf{A})$, IL-6 (B) and NO (D) while the IL-1 $\beta$ production was reduced $(\mathbf{C})$ in BV-2 microglia. Culture supernatants were analysed using ELISA following stimulation

by the spike $\mathrm{S} 1$ protein was further confirmed by results showing increased iNOS-mediated production of NO by the protein in microglia. Elevated iNOS/NO has been previously linked to a wide range of CNS disorders including Alzheimer's disease, Parkinson's disease, multiple sclerosis, epilepsy and migraine [44].
B

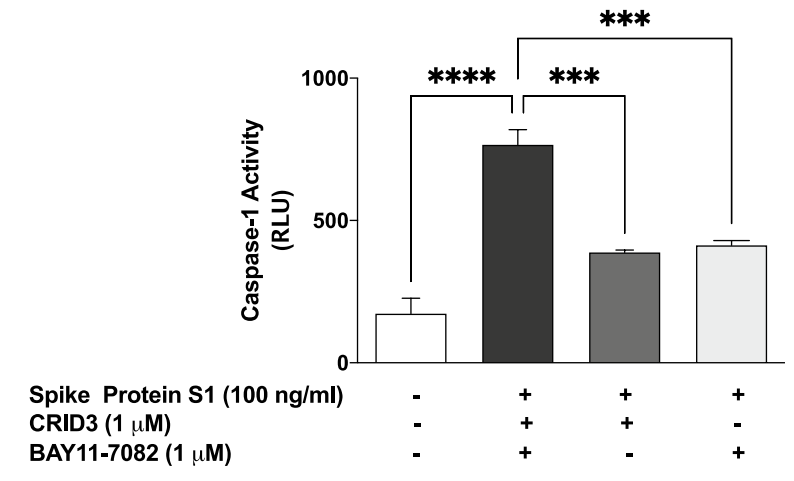

$(1 \mu \mathrm{M})$. Data were analysed using one-way ANOVA followed by a post hoc Tukey's multiple comparison test. $* p<0.05$, $* * * p<0.001$, $* * * * p<0.0001$, compared with untreated control or S1 stimulation alone

B
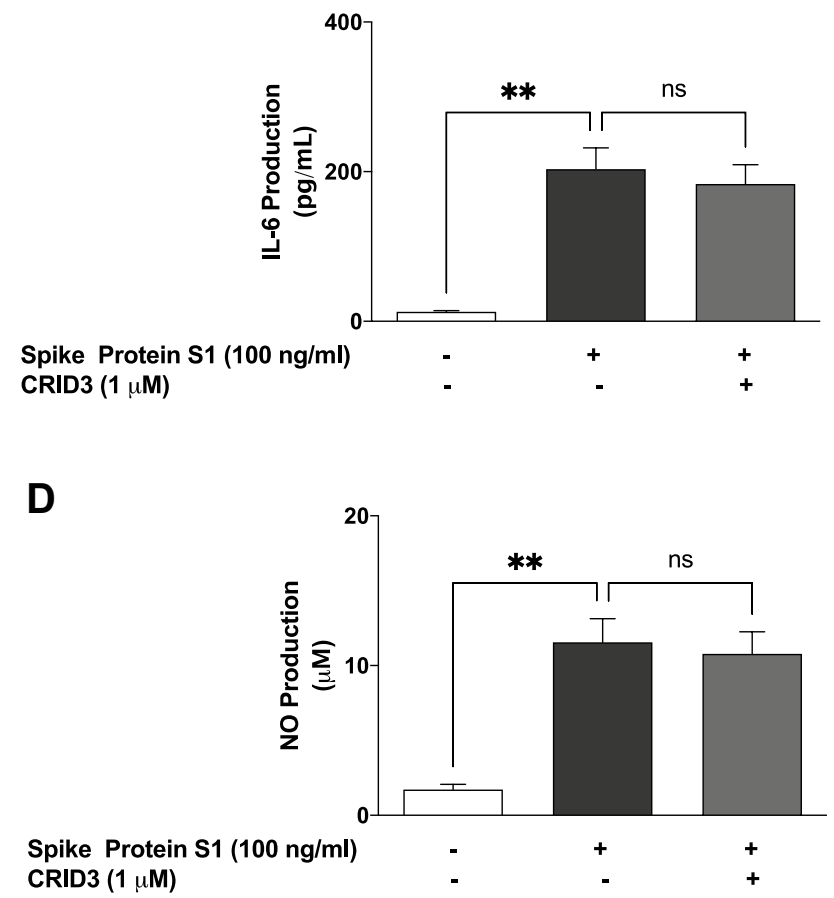

for $24 \mathrm{~h}$. Data were analysed using one-way ANOVA followed by a post hoc Tukey's multiple comparison test. $* * p<0.01$, $* * * p<0.001$, $* * * * p<0.0001$, ns (not significant at $p<0.05$ ), compared with untreated control or S1 stimulation alone

These are interesting outcomes, considering the roles played by microglial activation and subsequent increased release of pro-inflammatory mediators in neurological disorders. In Parkinson's disease for example, a significant increase in the expression of IL- $1 \beta$ was shown in the substantia nigra and frontal cortex, compared to controls [45]. 

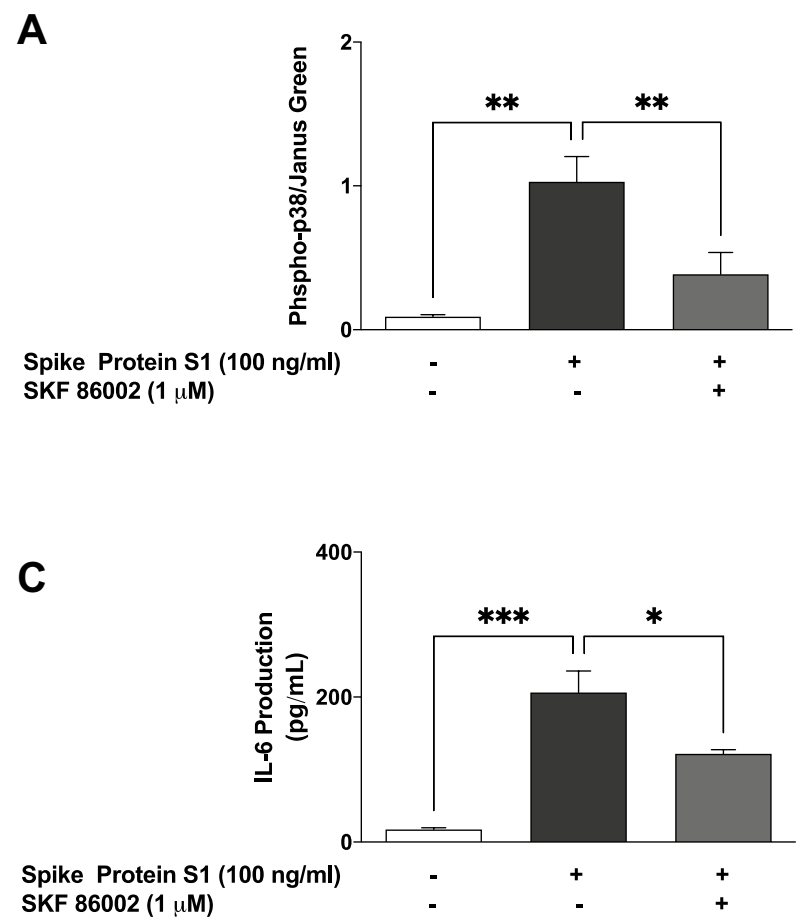

Fig. 8 Stimulation of BV-2 microglia with $\mathrm{S} 1(100 \mathrm{ng} / \mathrm{ml})$ increased the protein expression ofphospho-p38 MAPK (A), which wasinhibited in the presence of SKF $86002(1 \mu \mathrm{M})$. Data wereanalysed using one-way ANOVA followed by a post hoc Tukey's multiple comparisontest. $* * p<0.01$, compared withuntreated control or S1 stimulation alone. Effects of SKF $86002(1 \mu \mathrm{M})$ on S1-induced increased

Pro-inflammatory cytokine (IL-1 $\beta$, TNF- $\alpha$, IL-6) release has also been linked to depression-like behaviours and cognitive defects in mice [46]. Further studies are therefore needed to elucidate the link between COVID-19-mediated hyper-inflammation and the pathogenesis of neurological symptoms that have been reported to be associated with the disease.

In neuroinflammation, the NF- $\mathrm{kB}$ transcription factor regulates the production of multiple pro-inflammatory genes, including the pro-inflammatory cytokines such as TNF- $\alpha$, IL- 6 and IL- $1 \beta$, as well as iNOS. We further showed that activation of microglial NF- $\mathrm{KB}$ signalling mediates the production of pro-inflammatory mediators in the microglia by SARS-CoV-2 spike $\mathrm{S} 1$ protein through its ability to promote cytoplasmic phosphorylation of the p65 sub-unit and I $\mathrm{I} \mathrm{B} \alpha$, as well as the DNA binding of p65 sub-unit and NF- $\mathrm{kB}$ transcriptional activity. Interestingly, these effects were blocked by the potent NF- $\kappa B$ inhibitor BAY11-7082. The involvement of NF- $\mathrm{KB}$ in $\mathrm{S} 1$ protein-induced neuroinflammation was further confirmed by results showing the effectiveness of BAY11-7082 in blocking S1-induced production of TNF$\alpha$, IL-6 and IL-1 $\beta$, and iNOS/NO in BV-2 microglia. In a similar study reported by Patra et al. [47], SARS-CoV-2 spike protein was shown to promote IL-6 signalling through
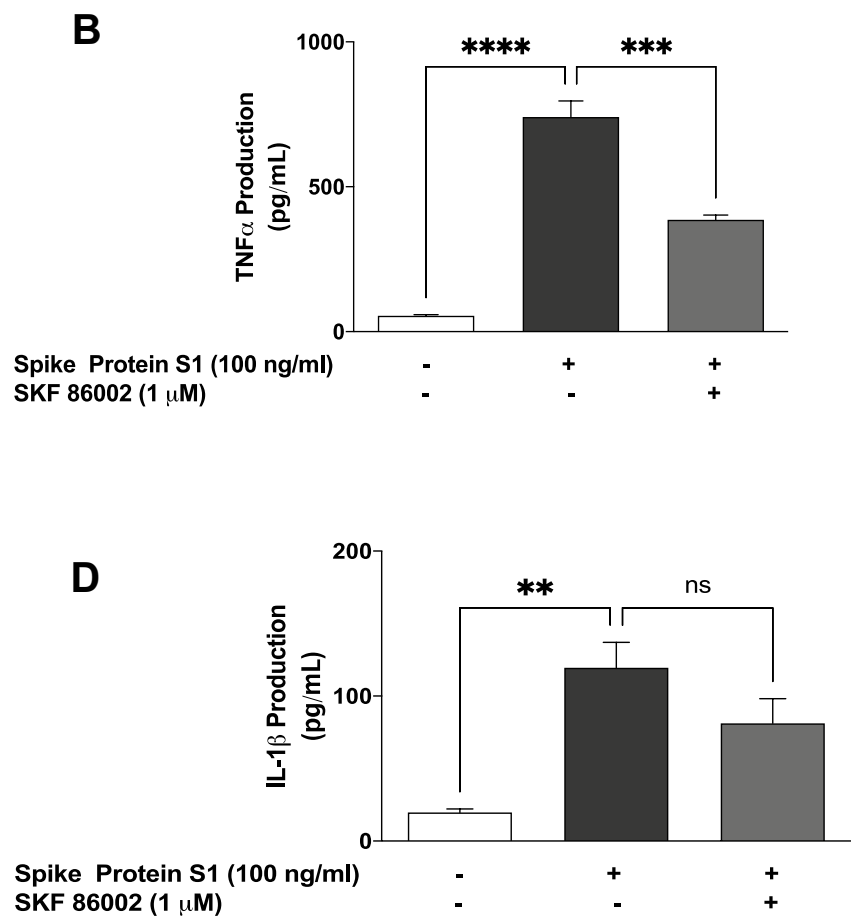

production of TNFa (B), IL-6 (C) and IL-1 $\beta$ (D) in BV-2microglia. Culture supernatants were analysed using ELISA following stimulationfor $24 \mathrm{~h}$. Data were analysed using one-way ANOVAfollowed by a post hoc Tukey's multiple comparison test. ${ }^{*} p<0.05,{ }^{*} p<0.01$, $* * * p<0.001, * * * * p<0.0001$, ns (not significant at $p<0.05$ ), compared with untreated control, or S1stimulation alone

$\mathrm{NF}-\mathrm{\kappa B}$ in epithelial cells to initiate coordination of a hyperinflammatory response. To our knowledge, this is the first evidence demonstrating the role of NF- $\mathrm{KB}$ activation in S1-induced microglial activation.

Reports in scientific literature suggest that the NLRP3 inflammasome may be contributing to the release of cytokines such as IL-1 $\beta$ in SARS-CoV-2-induced hyperinflammation [48-50]. In the microglia, activation of NLRP3 by extracellular ATP, certain bacterial toxins and crystalline and particulate matters results in caspase- 1 activation which then cleaves the precursors of IL- $1 \beta$ and IL-18 to generate active IL- $1 \beta$ and IL- 18 , resulting in neuroinflammation and pyroptosis [51-53]. In this study, we showed that in addition to increasing IL- $1 \beta$ production, SARS-CoV-2 spike $S 1$ protein activated NLRP3 inflammasome and increased caspase- 1 activity in BV-2 microglia. These effects were also shown to be attenuated by CRID3 and BAY11-7082, which are known inhibitors of NLRP3. Furthermore, pre-treatment of BV-2 microglia with CRID3 prevented SARS-CoV- 2 spike S1 protein-induced IL- $1 \beta$ production, but not TNF- $\alpha$, IL- 6 or NO, suggesting an involvement of the NLRP3 inflammasome activation in neuroinflammation induced by $\mathrm{S} 1$ in $\mathrm{BV}-2$ microglia. The observed effects of BAY11-7082 on both NF-kB 
A

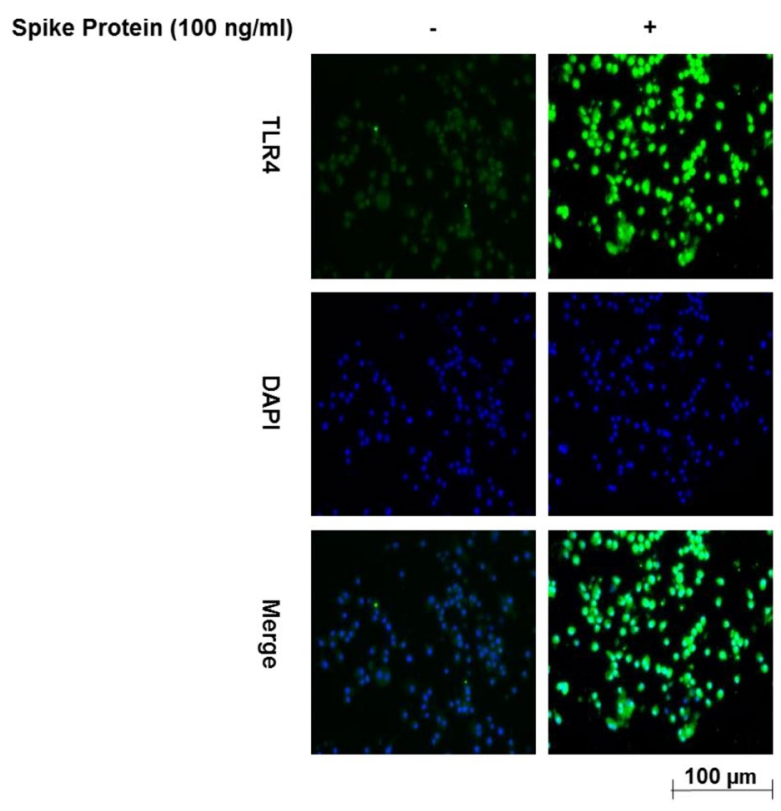

B

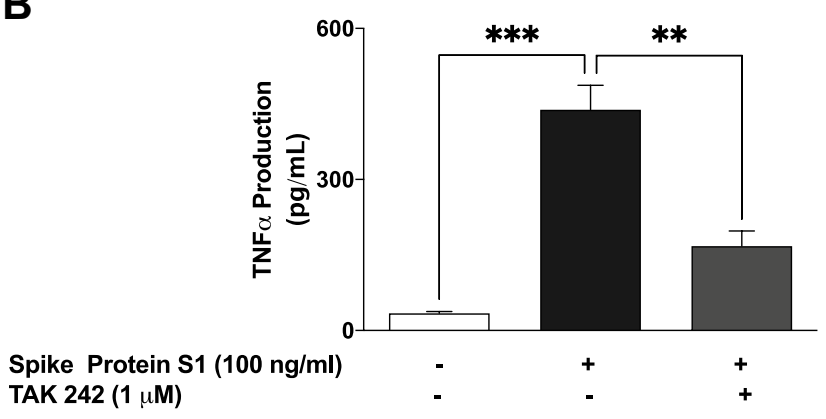

D

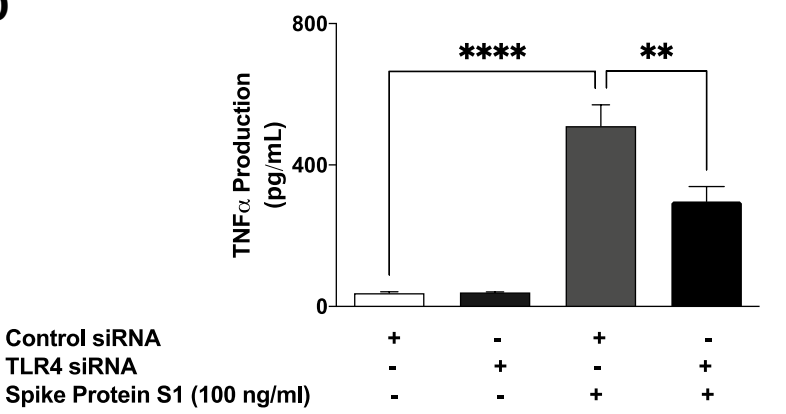

Fig. 9 Immunofluorescence microscopy showing anincrease in TLR4 protein expression following stimulation of BV-2 microgliawith S1 (100 ng/mL) (A).Pre-treatment of S1-stimulated BV-2 microglia with TAK $242(1 \mu \mathrm{M})$ reduced the production of TNF $\alpha(\mathbf{B})$ and IL-6 (C). Data were analysed using one-way ANOVA followed by a post hocTukey's multiple comparison test. $* p<0.05$, $* * p<0.01$,

and NLRP3 activation in S1-stimulated BV-2 microglia reflect a potential therapeutic benefit of this compound in SARS-CoV-2 infection. Previous studies on this inhibitor of NF- $\mathrm{KB}$ have shown that it improved survival and

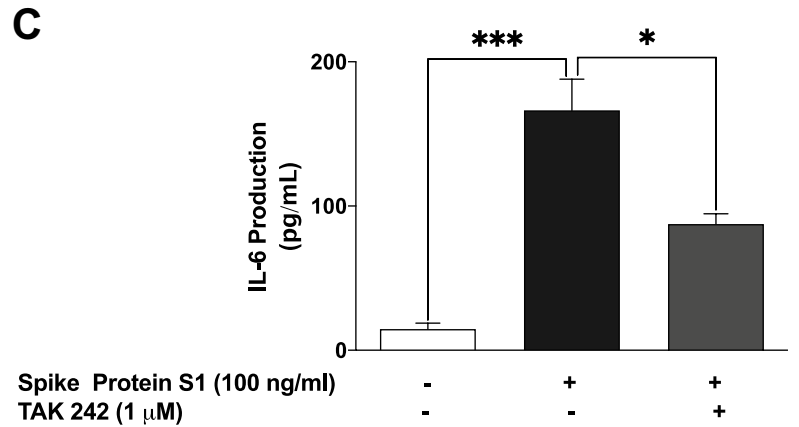

$\mathbf{E}$

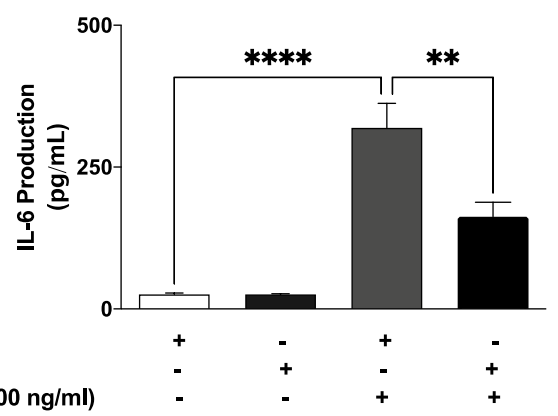

$* * * p<0.001$, compared withuntreated control, or S1 stimulation alone. Transfection of S1-stimulated BV-2microglia with mouse TLR4 siRNA reduced TNF $\alpha(\mathbf{D})$ and IL-6 production (E).Data were analysed using one-way ANOVA followed by a post hoc Tukey's multiplecomparison test. $* * p<0.01, * * * * p<0.0001$, control siRNA versus TLR4 siRNA

reduced pro-inflammatory cytokine levels in the lungs of SARS-CoV-infected mice [54].

It has been suggested that activation of NF- $\mathrm{KB}$ could trigger NLRP3 through caspase-1, with subsequent release 
of mature IL-1 $\beta$ [55]. It is not clear from this study if the activation of NLRP3/caspase-1 by S1 was due to a direct effect on NLRP3 or an indirect action as a result of activating NF- $\kappa B$. The role of NLRP3 inflammasome activation in $\mathrm{S} 1$-induced neuroinflammation therefore requires further investigation.

Our results showing activation of p38 MAPK by S1, coupled with inhibition of S1-induced increased production of TNF- $\alpha$ and IL- 6 by the p38 inhibitor (SKF 86002), suggest the involvement of the p38 MAPK signalling in its pro-inflammatory effect in BV-2 microglia. One possible explanation for this effect is the activation by $\mathrm{S} 1$ of upstream signals which activate both NF- $\mathrm{KB}$ and MAPK signalling in the microglia.

To explore the potential mechanisms involved in dual activation of NF- $\mathrm{\kappa B}$ and MAPK by S1 in BV-2 microglia, we conducted experiments that showed an increase in the expression of Toll-like receptor 4 (TLR4) by the protein. Interestingly, a known inhibitor of TLR4 signalling (TAK 242) inhibited S1-induced increased production of both TNF- $\alpha$ and IL-6, which further demonstrates a potential involvement of this pattern recognition receptor (PRR) in S1-induced neuroinflammation.

Our findings seem to confirm those reported from a study by Shirato and Kizaki [56], as they demonstrated involvement of TLR4 in the induction of pro-inflammatory responses in mouse and human macrophages by the SARS$\mathrm{CoV}-2$ spike protein $\mathrm{S} 1$ sub-unit. Similar observations linking TLR4 to induction of inflammation in THP-1 cells have been reported by Zhao et al. [57]. Studies to elucidate detailed modulatory effects of SARS-CoV-2 spike protein S1 sub-unit on microglia TLR4 signalling are required in order to provide a better understanding of the impact of SARS-CoV-2 infection on the brain.

The obtained results from these experiments have provided the first evidence demonstrating the activation of BV-2 microglia by SARS-CoV-2 spike S1 protein, resulting in the production of pro-inflammatory mediators TNF$\alpha$, IL-6, IL- $1 \beta$ and NO. We propose that induction of neuroinflammation by this protein in the microglia is mediated through activation of NF- $\mathrm{KB}$ and $\mathrm{p} 38$ MAPK, possibly as a result of TLR4 activation. These results contribute to our understanding of some of the mechanisms involved in CNS pathologies of SARS-CoV-2.

Supplementary Information The online version contains supplementary material available at https://doi.org/10.1007/s12035-021-02593-6.

Author Contribution Olumayokun A. Olajide: conceptualisation, methodology, investigation, writing of the original draft, writing which included review and editing and project administration. Victoria U. Iwuanyanwu, Oyinkansola D. Adegbola and Alaa A. Al-Hindawi: investigation.
Data Availability The datasets generated and/or analysed during the current study are available from the corresponding author on reasonable request.

\section{Declarations}

Ethics Approval and Consent to Participate Not applicable.

Consent for Publication Not applicable.

Conflict of Interest The authors declare no competing interests.

Open Access This article is licensed under a Creative Commons Attribution 4.0 International License, which permits use, sharing, adaptation, distribution and reproduction in any medium or format, as long as you give appropriate credit to the original author(s) and the source, provide a link to the Creative Commons licence, and indicate if changes were made. The images or other third party material in this article are included in the article's Creative Commons licence, unless indicated otherwise in a credit line to the material. If material is not included in the article's Creative Commons licence and your intended use is not permitted by statutory regulation or exceeds the permitted use, you will need to obtain permission directly from the copyright holder. To view a copy of this licence, visit http://creativecommons.org/licenses/by/4.0/.

\section{References}

1. World Health Organization (WHO). Novel coronavirus (2019$\mathrm{nCoV}$ ) situation reports

2. Yang R, Gui X, Xiong Y (2020) Patients with respiratory symptoms are at greater risk of COVID-19 transmission. Respir Med 165:105935

3. Pollard CA, Morran MP, Nestor-Kalinoski AL (2020) The COVID-19 pandemic: a global health crisis. Physiol Genomics 52:549-557

4. Zhang L, Peres TG, Silva MVF, Camargos P (2020) What we know so far about Coronavirus Disease 2019 in children: a meta-analysis of 551 laboratory-confirmed cases. Pediatr Pulmonol 55:2115-2127

5. Carsana L, Sonzogni A, Nasr A, Rossi RS, Pellegrinelli A, Zerbi P, Rech R, Colombo R, et al (2020) Pulmonary post-mortem findings in a series of COVID-19 cases from Northern Italy: a two-centre descriptive study. Lancet Infect Dis 20:1135-1140

6. Cataldi M, Pignataro G, Taglialatela M (2020) Neurobiology of coronaviruses: potential relevance for COVID-19. Neurobiol Dis 143:105007

7. Iadecola C, Anrather J, Kamel H (2020) Effects of COVID-19 on the nervous system. Cell 183:16-27.e1

8. Mao L, Jin H, Wang M, Hu Y, Chen S, He Q, Chang J, Hong C, et al (2020) Neurologic manifestations of hospitalized patients with coronavirus disease 2019 in Wuhan. China JAMA Neurol 77:683-690

9. Buzhdygan TP, DeOre BJ, Baldwin-Leclair A, McGary H, Razmpour R, Galie PA, Potula R, Andrews AM, et al (2020) The SARS-CoV-2 spike protein alters barrier function in 2D static and 3D microfluidic in vitro models of the human bloodbrain barrier. Neurobiol Dis 146:105131

10. Yachou Y, El Idrissi A, Belapasov V, Ait Benali S (2020) Neuroinvasion, neurotropic, and neuroinflammatory events of SARS-CoV-2: understanding the neurological manifestations in COVID-19 patients. Neurol Sci 41:2657-2669 
11. Bodnar B, Patel K, Ho W, Luo JJ, Hu W (2021) Cellular mechanisms underlying neurological/neuropsychiatric manifestations of COVID-19. J Med Virol 93:1983-1998

12. Colonna M, Butovsky O (2017) Microglia function in the central nervous system during health and neurodegeneration. Annu Rev Immunol 35:441-468

13. Nimmerjahn A, Kirchhoff F, Helmchen F (2005) Resting microglial cells are highly dynamic surveillants of brain parenchyma in vivo. Science 308:1314-1318

14. Cartier N, Lewis CA, Zhang R, Rossi FM (2014) The role of microglia in human disease: therapeutic tool or target? Acta Neuropathol 128:363-380

15. Du L, Zhang Y, Chen Y, Zhu J, Yang Y, Zhang HL (2017) Role of microglia in neurological disorders and their potentials as a therapeutic target. Mol Neurobiol 54:7567-7584

16. Mahad DJ, Ransohoff RM (2003) The role of MCP-1 (CCL2) and CCR2 in multiple sclerosis and experimental autoimmune encephalomyelitis (EAE). Semin Immunol 15:23-32

17. Loane DJ, Byrnes KR (2010) Role of microglia in neurotrauma. Neurotherapeutics 7:366-377

18. Michell-Robinson MA, Touil H, Healy LM, Owen DR, Durafourt BA, Bar-Or A, Antel JP, Moore CS (2015) Roles of microglia in brain development, tissue maintenance and repair. Brain J Neurol 138:1138-1159

19. Jimenez S, Baglietto-Vargas D, Caballero C, Moreno-Gonzalez I, Torres M, Sanchez-Varo R, Ruano D, Vizuete M, et al (2008) Inflammatory response in the hippocampus of PS1M146L/ APP751SL mouse model of Alzheimer's disease: age-dependent switch in the microglial phenotype from alternative to classic. J Neurosci 28:11650-11661

20. Varnum MM, Ikezu T (2012) The classification of microglial activation phenotypes on neurodegeneration and regeneration in Alzheimer's disease brain. Arch Immunol Ther Exp 60:251-266

21. Liao B, Zhao W, Beers DR, Henkel JS, Appel SH (2012) Transformation from a neuroprotective to a neurotoxic microglial phenotype in a mouse model of ALS. Exp Neurol 237:147-152

22. Cherry JD, Olschowka JA, O'Banion MK (2014) Neuroinflammation and M2 microglia: the good, the bad, and the inflamed. J Neuroinflammation 11:98

23. Gerhard A, Pavese N, Hotton G, Turkheimer F, Es M, Hammers A, Eggert K, Oertel W et al (2006) In vivo imaging of microglial activation with [11C](R)-PK11195 PET in idiopathic Parkinson's disease. Neurobiol Dis 21:404-412

24. Mondelli V, Vernon AC, Turkheimer F, Dazzan P, Pariante CM (2017) Brain microglia in psychiatric disorders. Lancet Psychiatry 4:563-572

25. Ikawa D, Makinodan M, Iwata K et al (2017) Microglia-derived neuregulin expression in psychiatric disorders. Brain Behav Immun 61:375-385

26. Dowlati Y, Herrmann N, Swardfager W, Liu H, Sham L, Reim EK, Lanctôt KL (2010) A meta-analysis of cytokines in major depression. Biol Psychiatry 67:446-457

27. Frick LR, Williams K, Pittenger C (2013) Microglial dysregulation in psychiatric disease. Clin Dev Immunol 2013:608654

28. Velagapudi R, Lepiarz I, El-Bakoush A, Katola FO, Bhatia H, Fiebich BL, Olajide OA (2019) Induction of autophagy and activation of SIRT-1 deacetylation mechanisms mediate neuroprotection by the pomegranate metabolite urolithin A in BV2 microglia and differentiated 3D human neural progenitor cells. Mol Nutr Food Res 63:e1801237

29 Olajide OA, Akande IS, da Silva Maia Bezerra Filho C, LepiarzRaba I, de Sousa DP (2020) Methyl 3,4,5-trimethoxycinnamate suppresses inflammation in RAW264.7 macrophages and blocks macrophage-adipocyte interaction. Inflammopharmacology 28:1315-1326
30. Velagapudi R, Kosoko AM, Olajide OA (2019) Induction of neuroinflammation and neurotoxicity by synthetic hemozoin. Cell Mol Neurobiol 39:1187-1200

31. Kandasamy M (2021) NF- $\kappa B$ signalling as a pharmacological target in COVID-19: potential roles for IKK $\beta$ inhibitors. Naunyn Schmiedebergs Arch Pharmacol 394:561-567

32. Coll RC, Robertson AA, Chae JJ et al (2015) A small-molecule inhibitor of the NLRP3 inflammasome for the treatment of inflammatory diseases. Nat Med 21:248-255

33. Lee JC, Kumar S, Griswold DE, Underwood DC, Votta BJ, Adams JL (2000) Inhibition of p38 MAP kinase as a therapeutic strategy. Immunopharmacology 47:185-201

34. Yamada M, Ichikawa T, Ii M, Sunamoto M, Itoh K, Tamura N, Kitazaki T (2005) Discovery of novel and potent small-molecule inhibitors of NO and cytokine production as antisepsis agents: synthesis and biological activity of alkyl 6-(N-substituted sulfamoyl)cyclohex-1-ene-1-carboxylate. J Med Chem 48:7457-7467

35. Takashima K, Matsunaga N, Yoshimatsu M, Hazeki K, Kaisho T, Uekata M, Hazeki O, Akira S, et al (2009) Analysis of binding site for the novel small-molecule TLR4 signal transduction inhibitor TAK-242 and its therapeutic effect on mouse sepsis model. Br J Pharmacol 157:1250-1262

36. Walls AC, Park YJ, Tortorici MA, Wall A, McGuire AT, Veesler D (2020) Structure, function, and antigenicity of the SARS-CoV-2 spike glycoprotein. Cell 181:281-292.e6

37. Duan L, Zheng Q, Zhang H, Niu Y, Lou Y, Wang H (2020) The SARS-CoV-2 spike glycoprotein biosynthesis, structure, function, and antigenicity: implications for the design of spike-based vaccine immunogens. Front Immunol 11:576622

38. Moradian N, Gouravani M, Salehi MA, Heidari A, Shafeghat M, Hamblin MR, Rezaei N (2020) Cytokine release syndrome: inhibition of pro-inflammatory cytokines as a solution for reducing COVID-19 mortality. Eur Cytokine Netw 31:81-93

39. Hirawat R, Saifi MA, Godugu C (2021) Targeting inflammatory cytokine storm to fight against COVID-19 associated severe complications. Life Sci 267:118923

40. Yang L, Liu S, Liu J, Zhang Z, Wan X, Huang B, Chen Y, Zhang Y (2020) COVID-19: immunopathogenesis and immunotherapeutics. Signal Transduct Target Ther 5:128

41. Olajide OA, Iwuanyanwu VU, Lepiarz-Raba I, Al-Hindawi AA (2021) Induction of exaggerated cytokine production in human peripheral blood mononuclear cells by a recombinant SARS$\mathrm{CoV}-2$ spike glycoprotein $\mathrm{S} 1$ and its inhibition by dexamethasone. Inflammation 44:1865-1877

42. Imai Y, Ibata I, Ito D, Ohsawa K, Kohsaka S (1996) A novel gene iba1 in the major histocompatibility complex class III region encoding an EF hand protein expressed in a monocytic lineage. Biochem Biophys Res Commun 224:855-862

43. Ito D, Imai Y, Ohsawa K, Nakajima K, Fukuuchi Y, Kohsaka S (1998) Microglia-specific localisation of a novel calcium binding protein, Iba1. Brain Res Mol Brain Res 57:1-9

44. Tripathi MK, Kartawy M, Amal H (2020) The role of nitric oxide in brain disorders: autism spectrum disorder and other psychiatric, neurological, and neurodegenerative disorders. Redox Biol 34:101567

45. Kouli A, Camacho M, Allinson K, Williams-Gray CH (2020) Neuroinflammation and protein pathology in Parkinson's disease dementia. Acta Neuropathol Commun 8:211

46. Zhang J, He H, Qiao Y, Zhou T, He H, Yi S, Zhang L, Mo L, et al (2020) Priming of microglia with IFN- $\gamma$ impairs adult hippocampal neurogenesis and leads to depression-like behaviors and cognitive defects. Glia 68:2674-2692

47. Patra T, Meyer K, Geerling L, Isbell TS, Hoft DF, Brien J, Pinto AK, Ray RB, et al (2020) SARS-CoV-2 spike protein promotes IL-6 trans-signaling by activation of angiotensin II receptor signaling in epithelial cells. PLoS Pathog 16:e1009128 
48. Freeman TL, Swartz TH (2020) Targeting the NLRP3 inflammasome in severe COVID-19. Front Immunol 11:1518

49. Chang YS, Ko BH, Ju JC, Chang HH, Huang SH, Lin CW (2020) SARS unique domain (sud) of severe acute respiratory syndrome coronavirus induces NLRP3 inflammasome-dependent CXCL10mediated pulmonary inflammation. Int J Mol Sci 21:3179

50. Rodrigues TS, de Sá KSG, Ishimoto AY et al (2021) Inflammasomes are activated in response to SARS-CoV-2 infection and are associated with COVID-19 severity in patients. J Exp Med 218:e20201707

51. Venegas C, Heneka MT (2017) Danger-associated molecular patterns in Alzheimer's disease. J Leukoc Biol 101:87-98

52. Zhang Y, Zhao Y, Zhang J, Yang G (2020) Mechanisms of NLRP3 inflammasome activation: its role in the treatment of Alzheimer's disease. Neurochem Res 45:2560-2572

53. Chang Y, Zhu J, Wang D et al (2020) NLRP3 inflammasomemediated microglial pyroptosis is critically involved in the development of post-cardiac arrest brain injury. J Neuroinflammation 17:219

54. DeDiego ML, Nieto-Torres JL, Regla-Nava JA et al (2014) Inhibition of NF- $\mathrm{KB}$-mediated inflammation in severe acute respiratory syndrome coronavirus-infected mice increases survival. J Virol 88:913-924

55. Kersse K, Bertrand MJ, Lamkanfi M, Vandenabeele P (2011) NOD-like receptors and the innate immune system: coping with danger, damage and death. Cytokine Growth Factor Rev 22:257-276

56. Shirato K, Kizaki T (2021) SARS-CoV-2 spike protein S1 subunit induces pro-inflammatory responses via toll-like receptor 4 signaling in murine and human macrophages. Heliyon 7:e06187

57. Zhao Y, Kuang M, Li J, Zhu L, Jia Z, Guo X, Hu Y, Kong J, et al (2021) SARS-CoV-2 spike protein interacts with and activates TLR41. Cell Res 31:818-820

Publisher's Note Springer Nature remains neutral with regard to jurisdictional claims in published maps and institutional affiliations. 